\title{
Multi-dimensional nature of the phenomenon of fraud in sales organizations. Undiscovered land of research opportunity
}

\author{
Krzysztof Cybulski*
}

Ethics as well as moral values are a powerful force which can regulate the behavior of salespeople, both inside and outside of an organization. While reasonably specific and easy to understand, ethics do not exhaust the list of determining factors which determine a person's propensity for fraud. There is a range of fraudulent activities which take place in companies which are not perceived as immoral or at least ethically doubtful. Authors of this text argue that fraud of organizational resources by salespeople is one of the most unrecognized and one of the most devastating phenomena in the modern sales force management practice. Fraud is a largely unrecognized phenomenon, and yet it deeply affects the results generated by companies, often significantly increasing the cost of doing business, as most sales executives indicate.

Keywords: organizational resource fraud, financial resource fraud, fixed asset fraud, data fraud, information fraud, customers fraud, personnel fraud, know-how fraud, reputation fraud, time fraud.

Submitted: 10.09.18 | Accepted: 16.12.18

\section{Wielowymiarowy charakter zjawiska defraudacji w organizacjach sprzedaży. Niezbadany obszar możliwości badawczych}

Kwestie etyczne, jak również wartości moralne, stanowia potężna sitę, która może regulować zachowanie sprzedawców wewnątrz organizacji i poza nia. Kwestie etyczne nie wyczerpuja listy czynników decydujących o skłonności jednostki do oszukańczych zachowań. Istnieje cata sfera nieuczciwych zachowań występujących w organizacjach, które nie sa powszechnie postrzegane jako niemoralne czy nawet jako watpliwe etycznie. Autor niniejszego tekstu dowodzi, że defraudacja zasobów organizacyjnych przez sprzedawców należy do jednej ze stabiej rozpoznanych, zarazem najbardziej dewastujacych organizacje praktyk spotykanych w praktyce zarzadzania organizacjami sprzedaży. Defraudacja jest zjawiskiem stabo rozpoznanym, ale poważnie wptywajacym na wyniki generowane przez organizacje. Większość menedżerów uważa, że często prowadzi ona do znaczacego wzrostu kosztów funkcjonowania dziatu sprzedaży.

Słowa kluczowe: defraudacja zasobów organizacyjnych, defraudacja finansowa, defraudacja środków trwałych, defraudacja informacji, defraudacja danych, defraudacja klientów, defraudacja personelu, defraudacja know-how, defraudacja reputacji, defraudacja czasu.

Nadesłany: 10.09.18 | Zaakceptowany do druku: 16.12.18

JEL: JOO

\footnotetext{
Krzysztof Cybulski - dr hab., Faculty of Management, University of Warsaw.

Correspondence address: Faculty of Management, University of Warsaw, 1/3 Szturmowa Street, 02-678 Warsaw.
} 


\section{Introduction}

Attitudes and behaviors of salespeople which do not adhere to recognized ethical standards are widespread in all types of sales organizations, regardless of the nature of the business or the environment in which they operate.

Unethical behavior of salespeople and sales managers can affect the company's market position both in the short and in the long-term perspective. It can be a source of significant financial loss, much of which can be difficult to identify or estimate, in particular over a long time horizon, as it comes disguised in the form of deterioration in the reputation of a company, loss of its customers or of best- selling performers and, ultimately, the fall in revenue and in profitability.

Understandably, for the past several decades there has been growing interest from theoreticians and practitioners of management in this ethical aspect of the functioning of sales organizations. However, until recently nearly all of the effort in research and all attention from managers was focused on the deviant behavior of salespeople towards the customers of the company. Negative consequences of such behavior are usually easier to register, they usually have direct financial manifestation in the form of loss of customers, drop in sales or depressed rates of growth. At the same time, a wide range of deviant behaviors of salespeople, which can best be termed fraud of organizational resources, remained beyond the scope of interest of managers and researchers.

Although symptoms of this type of behavior have long been part of a set of ethical problems perceived by sales organizations, actually no comprehensive approach to the problem of fraud has emerged. If the issue of fraud was ever identified, it was usually narrowed down to issues relating to the fraud of financial resources (money) or fraud of material resources while the aspect of fraud relating to other resources of an organization was ignored completely. In practice, organizations revealed considerable helplessness when confronted with fraud in all of its various manifestations. Organizations often reckoned fraud was an issue for which no effective remedy could be found (Liao, Mavondo and Kennedy, 2001).
The authors of this text intend to demonstrate how significant the issue of fraud of organizational resources by salespeople is both to theoreticians of organizations and to business practitioners. Subsequently, based on the study of literature, on observation of management practice and on direct interviews with a large group of sales managers of Polish companies conducted by the authors, they intend to identify the most characteristic symptoms and consequences of fraud. Additionally, an attempt is made to define a rational justification for an organization's strategy in response to fraud committed by salespeople.

Finally, we would like to point out the most important directions of research which we think should be pursued in order to further our understanding of the phenomenon of fraud of organizational resources by its sales personnel, to reduce the scale of fraud and, most importantly of all, to limit its destructive consequences to companies.

For the purposes of this paper we define fraud as any kind of theft or conscious waste of a sales organization's resources by its sales personnel. Theft of assets is only one of many forms of resource fraud. In our research a definition of organizational resources confluent with the so-called resource-based view was used as a reference point (Barney, 1991; Wright, Dundford and Snell, 2001).

The text will give examples of many more types of waste of resources by sales personnel and by sales managers, namely: fraud of (1) Financial Resources (money), (2) Fixed Assets, (3) Time, (4) Data, (5) Information, (6) Customers, (7) Reputation and (8) Personnel.

There are many reasons for which this kind of deviant behavior of sales personnel is likely one of the most challenging issues of modern sales management. One of such reasons is that many researchers of sales force management as well as business practitioners do not perceive many of the above mentioned phenomena as fraud. Although the phenomenon is wide-spread, it may seem illusive as its scale varies strongly between countries, businesses and individual companies. Furthermore, the phenomenon has not been studied in any comprehensive way. The above translates into the fact that both the theorists and the practitioners of management register 
symptoms of fraud but rarely treat them as an element of a bigger problem.

Various forms of fraud described below are usually closely related. For example, time fraud will usually have direct consequences in a decrease in the level of quality of customer service, ultimately leading to loss of customers and a drop in the company's revenue. Also interesting is the correlation between the type of fraud and the time it occurs. For example, while fraud of time, money and of material resources happens exclusively while the sales person or manager is working for an organization, information fraud, client and personnel fraud all mostly take place after that relationship terminates.

Fraud is particularly damaging if it relates to the strategic resources of an organization, such as its client base or its key salespeople. In the opinion of many authors as well as of management practitioners, a company's pool of clients is its most valued resource, and any fraud within that pool leads to serious and often irreversible loss (Kotler, 2004, pp. 21-22, 23-24; Zoltners, Sinha and Lorimer, 2016). The same can be said about the key salespeople whose importance to the success of a company is becoming increasingly evident to decision makers (Zoltners, Sinha, Lorimer, 2016). The loss of good salespeople as a result of fraud by an ex-sales manager may become an even bigger issue in the long-run than the loss of a key customer as it may directly translate into an irreversible erosion of a company's competitive advantage in the market. In contrast, money and time fraud are in essence perceived more as an organizational issue or a technical issue rather than a key challenge to a company's management.

Interestingly, the traditional taxonomy of deviant behavior in a sales organization, which is presented below, does not single out fraud as a separate, fundamentally and qualitatively isolated type of unethical attitude or behavior of sales personnel.

\section{Traditional taxonomy of deviant behaviors in sales organizations}

Studies and practical observations suggest that five specific sets of deviant behaviors in sales organizations can be isolated (Anderson, Hair and Bush, 1999, from 14-5 till 149).
The first set is embedded in the manager's dealings with salespeople. Ethical issues in the relationship between sales managers and their sales force include such things as lack of fairness and unequal treatment of employees in hiring and in promotion, lack of respect for an individual in supervision and in designing of training programs, as well as unequal treatment and lack of integrity in the designing of sales territories and in the assignment of salespeople to territories.

Thus ethical issues pervade nearly all aspects of sales force management (Johnston and Marshall, p. 18). For instance, if a company unexpectedly increases the number of sales territories, which often necessitates territories to be split or reduced in size, the earnings of individual salespeople are usually reduced. If a sales manager is not consistent across all his team in the amount of sales pressure exerted, important ethical dilemmas can follow, in particular if the company is also guilty of setting unrealistic or unobtainable sales targets (Futrell, 2003, pp. 40-41).

The second set of deviant issues arises from the interactions between salespeople and their customers. This section focuses on such unethical behaviors of salespeople as gifting, both current customers and prospects, revealing confidential information, overpromising and overselling, distorting the truth. This area also includes a range of preferential treatment by salespeople of particular prospects and customers (Churchill et al., 2000, pp. 79-83). Generally, unethical sales practices make buyers reluctant to deal with a company and are likely to result in the loss of sales and profits over time. Additionally, lapses in ethical conduct have been known to lead to legal problems (Ingram et al., 2001, pp. 69-74).

A number of inappropriate relations between sales team members generate the third set of deviant behaviors, which could seriously hit sales organizations. Most common are: (1) taking customers from co-sales, (2) undercutting co-workers and (3) various forms of mobbing. Some excessively target-oriented salespeople may resort to various unethical behaviors to increase outcomes by slipping over into another salesperson's territory to obtain sales or by persuading a customer to make all purchases from one's own territory. 
Undercutting co-workers consists of various forms of unethical internal competition among sales team members such as covering up one's own slip-up by claiming that a secretary failed to relay a telephone message, or informing a customer that another salesperson doesn't provide good after-sales service to customers. Salespeople quite often may become perpetrators or victims of various forms of mobbing and of sexual harassment, which in many countries are not only unethical but also illegal (Ferrell, Johnston and Ferrell, 2007).

Rising competition among companies may stimulate a number of further examples of deviant behaviors of company salespeople in relations with their market rivals, such as making disparaging remarks about competitive products or services, disrupting competitors' product displays or snooping on competitors. These behaviors are aimed at obtaining competitively useful information through unethical means. This establishes the fourth set of deviant sales personnel behaviors. For example, salespeople may pump competitors' salespeople at social gatherings, encourage customers to inform the company on competitors' price offerings, or pretend to be customers at professional conferences, trade shows, or on plant tours (Ingram et al., 2001, pp. 69-74).

The fifth realm of ethical problems of sales organizations is related to ethically doubtful relations of their sales personnel to their companies. A vast range of unethical or deviant behaviors which commonly manifest themselves in companies can be identified here: cheating in sales contests, falsifying sales records and bending ethical rules (Anderson, Hair and Bush, 1999).

But such deviant activities do not exhaust all unethical behaviors of sales personnel. We could easily indicate a range of different behaviors which could be termed as fraud. In the long run in particular, could they boomerang to hurt the company as a whole, its employees and its customers who, as a result, could be charged higher prices. In the present text we entirely focus on organizational resource frauds by sales personnel. Although not widely recognized, these behaviors can, in our opinion, seriously affect the well-being of companies. Quite frequently what is perceived as a small abuse of standards may spiral into a significant increase in the cost of doing business (Anderson, Hair and Bush, 1999, p. 14-5).

\section{Characteristics of the job of a salesperson}

Sales jobs differ from other jobs. Sales force is largely responsible for implementing a firm's marketing strategies in the field. In order to be successful in sales, a sales representative needs to work hard, both physically and mentally, be creative and persistent, and show considerable initiative. Salespeople are frequently required to develop innovative solutions to difficult problems. Sales representatives do not always succeed in closing the deal and they must be able to handle the negative feelings associated with sale opportunities they miss.

Often salespeople are required to socialize with customers who frequently are top managers in their companies. Sales representatives often operate with little or no direct supervision, they require a high degree of motivation and are responsible for managing their own time.

Opinions about the firm and its products are formed on the basis of impressions which, rather than from observations of the factory work or of the work of its office staff, comes from contact with salespeople and their managers. On the other hand, salespeople are responsible for channeling information about customer needs and problems back to various departments in their own firms.

It is crucial, from both the short and the long-term perspective, that salespeople are successful in generating revenue to the company. In order to do so, they are among the few employees authorized to spend company funds: they spend company money on entertainment, rooms, food, transportation, and other business expenses. They are also responsible for proper use of cars, laptops and other electronic devices provided by the company to support their sales activities. Their effectiveness and diligence in discharging this responsibility significantly influences marketing costs and company profits. Thus the sales personnel is not only the most important generator of revenue to the company, it is also largely responsible for proper and cost-effective utilization of organizational resources. 


\section{The essence and main symptoms of fraud by sales personnel}

The essence of resource fraud is the intentional action of sales personnel or sales managers, triggered by diverse motivations, which leads to depletion or destruction of an organization's resources. Thus, fraud should be clearly distinguished from cases where such depletion or destruction of resources is caused by sales personnel or managers but as the result of negligence, unprofessional behavior or of unavoidable and unfavorable coincidence.

Although any act of so defined fraud is an act of misappropriation of a company's resources by a member of its sales staff, motivations for such acts vary widely. Often the motivation comes from the simple want of financial gains. This is the case when a salesperson, or more often a manager, discloses valuable secrets of their current employer to a competitive company in exchange for direct financial benefits.

In many cases, however, the promise of direct financial gains is not the determinant factor when it comes to fraud. Often, the act of fraud committed by a member of a company's sales staff is a manifestation of that person's will to reestablish what they perceive as organizational justice. Sales personnel as well as managers often experience a strong feeling of organizational injustice which stems from the level of remuneration and which takes on the form of perception of distributive injustice. Fraud of financial resources or of material assets may be a response aimed at correcting such "unfair organizational allocation of benefits" (Brashear and Boles, 2003; Chang and Dubinsky, 2005).

The prevalent motivation for fraud, however, is the perceived need of a salesperson to obtain a stronger position in a new company. When a sales person leaves a company to join a new employer, they often take along, or defraud, a pool of customers. An analogous situation is where a manager who is leaving a company takes along some of the sales personnel of their former employer. This is probably the most potentially devastating kind of fraud to a sales organization, not least for the fact that it is often accompanied by fraud of data and of information.

Financial fraud is defined as a reduction (loss) of financial resources of a company as a result of irrational (wasteful) use of resources or use of resources contrary to the objectives and tasks set to the sales personnel. Financial resources which are defrauded by a member of the sales personnel are often perceived by that person as a specific financial bonus which, obviously, has no affinity to the quality or the effect of their work.

A number of symptoms of this type of fraud may be distinguished. Salespersons inflate expense claims, they cheat in call reports and manipulate sales figures if, for example, they are competing in a sales contest or competing for a bonus (Anderson, Hair and Bush, 1999, p. 14-7).

Fraud of material assets is the unnecessary consumption or loss of a company's assets which is the result of irrational or wasteful use of such assets (for example, lack of due care in using assets entrusted by the company to a member of the sales staff), use of assets contrary to company objectives and contrary to the tasks set to a member of the sales staff. Fraud of assets can also manifest itself in simple theft (misappropriation). These actions can relate to assets which are made available to the sales staff to support their activities, for example to laptops or cell phones, but also through intentional negligence leading to damage to or loss of resources.

Authors of the text identified a number of motivations which lead to this kind of behavior. Although sometimes these motivations look bizarre, they all cast light on the dark side of sales organizations. Fraud is often a reaction of sales personnel to the injustice in remuneration they perceive and signal to their superiors. Sales personnel and managers are sometimes disappointed with the lack of promotion or bonus. Cases have been known where unhappy salespeople took revenge on the company by destroying cars, laptops or presentation equipment they were equipped with by their employer.

Fraud of time is an activity which consists in the decrease or loss of time sales personnel or managers are obliged to dedicate to work for the benefit of the company, and which is the result of irrational (wasteful) use of time or use of time contrary to company objectives or tasks the company set to its salespeople and managers.

Salespeople are able to work more efficiently by appropriately sharing their 
time between customers, products, and sales activities. Allocation of sales efforts strongly influences a sales organization's profits. Many salespeople spend much of their working time not only ineffectively but also on things unrelated to work. This is often caused by poor planning and by the resulting "time traps". Sometimes, this type of fraud can take on the form of blatant cheating which, for example, is the case when a salesperson uses their working time to perform tasks for another company.

Data fraud is the misappropriation by sales personnel or by managers of an organization's data which relates to the company's internal affairs, its selling strategies or sales activities in general. Such data is subsequently made available to competitive companies in exchange for material benefits.

Data fraud and information fraud, described below, are among the most common unethical behaviors of sales personnel. The scale of the negative impact on sales organizations of such behavior, both in the short and in the long-run, is difficult if not impossible to estimate. As a result of this type of fraud, companies are often forced to remodel their sales plans and motivational systems, and they often lose their competitive position in the market.

Information fraud is the misappropriation or misuse by salespeople or managers of information they obtained on an exclusive or non-exclusive basis while performing their professional duties. Information is misappropriated in order to build or maintain a privileged position of a salesperson or a manager in the organization (for example in their relations with key customers), through which a salesperson or a manager may "own" a customer. The consequences and the symptoms of information fraud are similar to those of data fraud. Therefore, it is reasonable to analyze these two types of fraud together.

Brand fraud is understood by the authors of the text as actions undertaken by salespeople or by managers, intentionally or as a result of negligence or lack of diligence, which lead to the loss of a part or all of the company's customers, which degrade a company's reputation in the market or which tarnish the image of the company's brand. It is therefore justified to refer to this type of fraud as reputation fraud.
This type of fraud represents a dangerous area of deviant behavior in a sales organization, the effects of which can remain hidden to the organization's managers for a long time. The company loses clients, and sales and market shares drop while the organization is trying to identify the reasons of such downturn.

Client fraud is a relatively, and in some industries overwhelmingly common activity, through which salespersons or managers tend to take over sales leads, customers, contracts or orders for the benefit of a competitive company or of other organizations, in particular at a time when a salesperson or manager is changing jobs or when they are starting business on their own.

Personnel fraud consists in informal recruitment or head hunting of salespeople or sales managers of a company, often conducted by former employees of that company for the benefit of competitive companies or other organizations. Although client and personnel fraud are among the most commonly occurring unethical business practices, it is evident they have not become the subject of study or any broader theoretical reflection. This comes as a surprise, as even a casual glance at the subject shows that personnel fraud:

1. has the most serious and nearly exclusively negative effect on an organization,

2. can undermine a company's standing, its sales and profitability over a long time,

3. implies the concurrence of other types of fraud so the company affected risks to lose customers, data, information and usually its reputation, all at the same time.

It is worth noting that personnel fraud is often an intrinsic element of voluntary turnover of sales personnel and of sales managers. However, this aspect has not yet been adequately reflected in studies inquiring into the personnel turnover in sales organizations.

\section{Determinants of fraud in sales organizations based on the previous studies}

The significant variation of fraudulent behaviors by sales personnel, together with the deficit of empirical knowledge relating to its actual scale and its popular manifestations, make it difficult to clearly define the major factors which determine this danger- 
ous and growing phenomenon. Literature does nevertheless allow to formulate some hypotheses (Cadogan et al., 2008; Jelinek and Ahearne, 2006; Appelbaum, Deguire and Lay, 2005; Schweitzer, Ordonez and Douma, 2004). It should be observed that none of these studies refers directly to the issue of fraud, but to factors which influence the broadly defined ethical and unethical behaviors of salespeople. Nevertheless, these studies do give an interesting insight into the determinants of fraud and, most importantly, they may become a starting point to formulating a series of inspiring hypotheses.

Two groups of factors seem to have decisive influence on the ethical attitudes and behaviors of sales personnel. The first includes the ethical standards shared by sales personnel and understood as inseparable components of the corporate culture of the company. They determine the values and shape the ethical behaviors of sales personnel (Hunt, Chonko and Wood, 1989, p. 80). It would seem justified to assume that "the higher the ethical standards in the sales organization, the lower the probability of unethical behavior, including fraud" (Cadogan et al., 2008, p. 9).

It is unfortunately impossible to identify ex-ante any beliefs or, for that matter, standards of ethical behavior because the tools which are used to measure the ethical convictions of salespeople are based on opinions of the staff themselves and on the concept of the declarative system of values developed by the German philosopher Max Scheler (Bloosser, 1999).

Another group of determinants of ethical (or unethical) behavior of sales personnel are the specific factors attributed to individual sales managers, such as: (1) the systems they use to control their sales reports, (2) the dominating moral philosophy understood as a set of convictions and opinions relating to what is and what is not ethical in their own behavior and in the behavior of their sales reports (Cadogan et al., 2008, p. 10).

The control system is a set of measures which allow the manager to monitor, rate the performance of, manage and remunerate his sales reports. In essence, there are two alternative control systems. Managers can evaluate the performance of their reports by monitoring their behavior (actions) or by monitoring the results of their work (Oliver and Anderson, 1994).

If managers monitor the behavior of their reports, the sales staff are usually subject to close and direct supervision. Performance evaluation is therefore based on such elements as the activity of a salesperson, the selling techniques they use, their sales attitudes and the quality of the relationship they build with their customers. In this case a fixed component accounts for a relatively large part of a salesperson's remuneration and its level is largely determined by the strongly subjective opinion of a salesperson held by their manager (Oliver and Anderson, 1994).

A control system which, on the other hand, monitors the effects of a salesperson's work, gives salespeople considerable scope of freedom in shaping their behaviors. The range of measures used to evaluate a salesperson's performance is seriously limited. Usually, only the results generated by a salesperson are monitored, and not the set of behaviors which lead to those results (Oliver and Anderson, 1994). In this case, a large part of a salesperson's remuneration is made up of a commission on sales and of bonuses for over performance, while the subjective opinion of the manager influences the remuneration of a salesperson only to a small extent (Cadogan et al., 2008, pp. 11-12).

It may therefore be reasonably assumed that performance evaluation systems which monitor the behavior of salespeople may lead to increased ethical standards in sales teams, and indirectly to reduced risk of fraudulent behaviors by an organization's sales staff (Ingram, LaForge and Schwepker, 2001).

A manager's moral philosophy is essentially made up of two elements: idealism and moral relativism (Bass, Barnett and Brown, 1998). Managers, characterized by a high level of moral relativism do not base their opinions about the behavior of salespeople on any universal ethical standard, but rather upon their opinion of individuals relative to situations in which they operate (Forsyth, 1992, p. 462). It may be assumed that such managers are more tolerant when formulating opinions about ethically doubtful behaviors of their sales reports. Conversely, managers who are characterized by a high level of idealism are convinced that high and universal ethical standards apply 
to all and in all business circumstances. It is therefore reasonable to assume that high moral relativism of managers may lead to the lowering of ethical standards in sales teams, as is often evidenced by managers' acquiescence to unethical behaviors of their sales staff (Bass, Barnett and Brown, 1998).

Available ethical studies suggest the existence of a significant influence of certain specific characteristics of sales teams on unethical behaviors of their members. These characteristics are: (1) job insecurity, (2) communication, and (3) operational skills.

Job insecurity is defined as expectations regarding lack of continuation of one's job (Greenhalgh, Rosenblatt, 1984). It is believed that a climate in which sales employees perceive their jobs as insecure can damage the firm's ability to develop high ethical standards in sales teams (Cadogan et al., 2008). The reduction of job satisfaction and of commitment, which result from job insecurity, may lead to decreased willingness on the part of the sales team members to adopt organizational goals or to be committed to the well-being of the company (Jaworskim and Kohli, 1991; 1993).

Furthermore, Ashford, Lee and Bobko, (1989) and Warren, (2003) suggest in their papers that, in addition to reducing the company loyalty and enhancing resistance to change, job insecurity may lead to an increase in sabotage behaviors. In sales organizations these may be dysfunctional and unethical behaviors such as territory raiding, fraudulent expense claims, or damage to a firm's reputation. As a result, the greater the job insecurity of sales teams, the lower their ethical standards and probably the higher the propensity to defraud company of its organizational resources.

The level of cooperation in a sales team is another feature which can strongly influence the results of salespeople, and indirectly influence their ethical attitudes and behaviors (Yilmaz and Hunt, 2001).

The main form of cooperation in sales teams is the sharing of information between sales team members (Yilmaz and Hunt, 2001). This type of cooperation makes the behavior of salespeople "visible" to other members of the team, even if they work in isolation as is the case with salespeople who work in the field and who are home- based. Exchange of information between sales team members makes them sensitive to unethical attitudes and behaviors of other sales team members. As a result of increased peer pressure, general attitude to ethics may improve across the team and the ethical attitudes and behaviors of sales team members may be strengthened.

Reasonable pressure exerted by managers on sales staff to achieve sales goals usually leads to increased sales effectiveness (Schweitzer, Ordonez and Douma, 2004). Combined with an attractive and fair remuneration system, training targeted at developing useful sales skills and a rational control system, this will allow a company to maintain its financial liquidity and a strong competitive position in the market.

Observation of management practice and of results of empirical studies indicate that salespeople who are highly effective in achieving set targets are usually less keen to show unethical attitudes and behaviors than low-performing salespeople (Robertson and Anderson, 1993). This is consistent with common knowledge which would suggest that salespeople who are able to achieve whatever financial targets they set themselves through professional competence, proactiveness and diligence, will rarely resort to unethical methods and actions.

\section{Some popular opinions about fraud and prevention of fraud}

Over the last few decades the Polish economy has undergone profound transformation. The leap from a dramatically ineffective communist system to efficient market economy brought a number of unquestionably positive effects to local consumers, such as a vast increase in the variety and abundance of consumer goods and services. Polish companies fare remarkably well in a market characterized by intense competition from local and international companies. This is, in particular, reflected in the increasing competitiveness of sales activities of Polish companies. Observations of market practice show that standards of management and the quality of services supplied by sales personnel to their customers are steadily improving.

In the opinion of many organizations such as Transparency International, the ethical climate of doing business in Poland 
revealed a constant improvement during the years of market transformation. For example, in the year 2016 Poland ranked 29 out of 100 countries classified, and it scored 60 points on a scale of perception by citizens of corruption of the public sector, where 0 stands for a totally corrupt system and 100 stands for a corruption-free system.

Generally positive opinions about the performance and competitiveness of Polish companies are often accompanied by negative opinions about a relatively low level of ethics in the management of sales organizations in this country, and in particularly of the firm belief that the level of fraud of resources in sales organizations by its sales staff is relatively high. Although a study conducted by the authors of the text between the years 2015 and 2016 on a group of 84 sales managers in Polish companies from very different industries, failed to confirm these negative opinions, it did signal other disturbing phenomena.

Table 1. Sample structure

\begin{tabular}{|l|c|c|}
\hline \multicolumn{1}{|c|}{ Industry } & Size & Percentage \\
\hline Pharmaceutical & 12 & $14 \%$ \\
\hline Retailing & 16 & $19 \%$ \\
\hline Food industry & 14 & $17 \%$ \\
\hline $\begin{array}{l}\text { Chemical } \\
\text { industry }\end{array}$ & 8 & $10 \%$ \\
\hline $\begin{array}{l}\text { Banking and } \\
\text { Insurance }\end{array}$ & 13 & $15 \%$ \\
\hline $\begin{array}{l}\text { Health Care } \\
\text { Services }\end{array}$ & 14 & $17 \%$ \\
\hline Software & 7 & $8 \%$ \\
\hline Total & 84 & $100 \%$ \\
\hline
\end{tabular}

Source: own research $(n=84)$.

The study was conducted in the form of a questionnaire composed of 5 closedended and open-ended questions, and a statement of respondent particulars. Before the respondents were asked to fill out the questionnaire, they had been given information about the types of fraud discussed above. This information was given to the respondents in the form of a short, 10-15-minute multimedia presentation. Respondents supplied answers in writing to the following questions:
Q.1 Is there any fraud of organizational resources in the company which you work for?

Q.2 In your opinion, fraud of which of a company's organizational resources is the most common in Polish companies?

Q.3 In your opinion, fraud of which of your company's organizational resources is the most challenging (is the biggest threat) to your company?

Q.4 In your opinion, what is an effective means of protecting against (preventing) fraud of organizational resources?

Q5. In your opinion, is it possible to eliminate fraud of organizational resources by sales personnel?

The study showed that:

- $75 \%$, i.e. the majority, of respondents were of the opinion that "there is no fraud in my company or the scale of fraud is small". Only 10\% of mangers see fraud as a significant and growing issue.

- Time fraud was unanimously named as the most common type of fraud in sales teams and by sales managers in Polish sales organizations, followed by a number of symptoms of financial fraud. The issues of personnel fraud and of customer theft were not named as a significant challenge to organizations, despite the fact that their actual scale in the Polish market seems alarmingly large (see Cybulski, 2013).

- In the opinion of nearly $50 \%$ of the sales managers surveyed, the two most common forms of fraud were fraud of time and finance, i.e. the two types of fraud which had earlier been identified as the most common.

- Respondents identified a number of methods to counteract fraud which they knew and which they considered effective. These methods rank as follows: (1) development of various forms of internal control including ongoing monitoring of activities of sales personnel (in particular those who work in the field), (2) verification of data (information) about the activities of the sales personnel, (3) verification of sales calls made by sales personnel.

In addition, respondents indicated other methods to eliminate and reduce fraud, albeit far less frequently: recruitment and hiring of the right people, and fair remuneration of sales personnel. Lastly, respondents did not favor codes of ethics 
or codes of conduct, or special procedures, which are so popular in international companies, as an effective means of eliminating fraud.

The sales managers surveyed were in agreement that the reduction of fraud to a low level or the total elimination of fraud is not possible, because of how specific the work in sales is, and because the monitoring and security systems currently in existence are either suboptimal or too expensive. As many as $60 \%$ of respondents expressed the opinion that tolerance for a certain level of fraud by a company's management may be the most reasonable of all policies.

\section{Conclusions}

(1) Fraud of company resources by its sales personnel is a widespread phenomenon and, although its scale can vary, it affects virtually all sales organizations, regardless of their size, industry or business environment in which they operate.

(2) The study conducted on managers by the authors of this text indicates that according to most of them, in principle fraud cannot be avoided. Therefore, losses which result from fraud should be treated as a cost of doing business.

(3) The scale of fraud and the degree of dysfunctionality vary a lot. Fraud ranges from the easily identified theft by sales personnel and by sales managers of a company's financial resources and time to fraud of data and information and, most importantly, to the destruction of a company's reputation and theft of its clients and key employees.

(4) Due to the specific character of work of salespeople and of sales managers, total elimination of fraud seems impossible. Salespeople have an easy, and often unrestricted, access to important corporate resources, which naturally creates the temptation to commit fraud.

(5) Salespeople, particularly the ones who operate in the field, are very difficult to control. Awareness among sales force management of the scale and of the negative effects of fraud committed by sales personnel is limited.

(6) It is reasonable to assume that only some manifestations of fraud are sys- tematically monitored. Even if organizations are aware of the possible fraud committed by their sales personnel, this problem is often deliberately underestimated and the perception of the scale of fraud is scarce.

(7) Organizations should foremostly identify categories of fraud which are the most damaging in their particular business situations. They should then make a register of negative consequences in each fraud category. It is then necessary to conduct a detailed analysis of the inside and outside determinants of each fraud category.

(8) It seems the awareness of fraud of organizational resources among Polish managers is limited and their perception of this phenomenon is limited to time and financial fraud.

(9) The managers surveyed have limited knowledge of effective methods of preventing fraud and of reducing the scale of fraud of resources in their companies.

(10) The survey shows that managers are characterized by a considerable degree of moral relativism which, in practical terms, translates into their acceptance of fraud in their organizations.

\section{References}

Anderson, R.E., Hair, J.F. and Bush, A.J. (1999). Professional Sales Management. Houston, TX: DAME Publications, Inc.

Appelbaum, St.H., Deguire, K.J. and Lay, M. (2005). The relationship of ethical climate to deviant workplace. Corporate Governance, 5, 4.

Ashford, S., Lee, C. and Bobko, Ph. (1989). Content, Causes, and Consequences of Job Insecurity: A Theory-Based Measure and Substantive Test. Academy of Management Journal, 32(4), 803-829.

Barney J.B. (1991). Firm Resources and Sustained Competitive Advantage. Journal of Management, 11(2).

Bass, K., Barnett, T. and Brown, G. (1998). The Moral Philosophy of Sales Managers and its Influence on Ethical Decisions Making. Journal of Personal Selling and Sales Management, XVIII(2), 1-17.

Bloosser, Ph. (1999). Six Questions Concerning Scheler's Ethics. Journal of Value Inquiry, 33, 2.

Brashear, Th.G., Brooks, Ch.M. and Boles, J.S. (2003). Distributive and procedural justice in a sales force context: Scale development and validation. Journal of Business Research, 57. 
Cadogan, J.W., Lee, N., Tarkiainen, A. and Sindqvist, S. (2008). Sales Manager and Sales Team Determinants of Salesperson Ethical Behavior, Research Paper.

Chang, Ch.Ch. and Dubinsky, A.J. (2005). Organizational Justice in the Sales Force: A Literature Review with Propositions. Journal of Business-toBusiness Marketing, 12(1).

Churchill, G.A. Jr., Ford, N.M., Walker O.W. Jr., Johnston, M.W. and Tanner, J.F. Jr. (2000). Sales Force Management, Sixth Edition. Irwin McGraw0Hill.

Cybulski, K. (2013). Zjawisko fluktuacji sprzedawców $w$ świetle badań empirycznych. Warszawa: Wydawnictwo Naukowe Wydziału Zarządzania Uniwersytetu Warszawskiego.

Ferrell, O.C., Johnston, M.W. and Ferrell, L. (2007). A Framework For Personal Selling And Sales Management Ethical Decision Making. Journal of Personal Selling and Sales Management, XXVII(4), 327-344.

Forsyth, D.R. (1980). A Taxonomy of Ethical Ideologies. Journal of Personality and Social Psychology, 39(1), 175-184.

Futrell, Ch.M. (2003). ABC's of Relationships Selling, $7^{\text {th }}$ International Edition, McGraw Hill Irwin.

Greenhalgh, L. and Rosenblatt, Z. (1984). Job Insecurity: Toward Conceptual Clarity. The Academy Management Review, 9(3), 438-448.

Hunt, Sh., Wood, V.R. and Chonko, L.B. (1989). Corporate Ethical Values and Organizational Commitment in Marketing. Journal of Marketing, 53(3), 79-90.

Ingram, Th.N., LaForge, R.W. and Schwepker, Ch.H. (2001). Salesperson Ethical Decision Making: The Impact of Sales Leadership and Sales Management Control Strategy. Journal of Personal Selling and Sales Management, XVII(4), 291-99.

Ingram, Th.N., LaForge, R.W., Avilla, R.A., Schwepker, Ch.H., Williams, M.R. (2001). Professional Selling. A Trust-Based Approach. Hardcourt College Publishers.

Jaworski, B.J. and Kohli, A.K. (1991). Supervisory Feedback: Alternative Types and Their Impact on Salespeople's Performance and Satisfaction. Journal of Marketing Research, 28 May, 190-201.

Jaworski, B.J. and Kohli, A.K. (1993). Market Orientation: Antecedents and Consequences, Journal of Marketing, 57, 53-70.
Jelinek, R. and Ahearne, M. (2006). The ABC's of ACB: Unveiling a clear and present danger in sales force. Industrial Marketing Management, 35, 457-467.

Jelinek, R. and Ahearne, M. (2006). The Enemy Within: Examining Salesperson Deviance and Its Determinants. Journal of Personal Selling and Sales Management, XXXVI, 4, 327-344.

Johnston, M.W. and Marshall G.W. (2001). Churchill/Ford/Walters's Sales Force Management, $8^{\text {th }}$ Edition. McGraw - Hill International Edition.

Kotler, Ph. (2004). Ten Deadly Marketing Sins. Sins and Solutions. John Wiley and Sons, Ltd.

Liao, Y., Mavondo, F. and Kennedy, R. (2001). Organisational Justice and Sales Force Motivation, Working Paper, Monash University.

Misztak, M., Niestrój, A. and Wajler, R. (2003). Zapobieganie defraudacji handlowej. Manager, 5.

Oakes, G. (1983). The Sales Process and Paradoxes of Trust. Journal of Business Ethics, August.

Oliver, R.L. and Anderson, E. (1994). An Empirical Test of the Consequences of Behavior - and Outcome-Based Sales Control Systems. Journal of Marketing, 58, 53-68.

Robertson, D.C., Anderson, E. (1993).Control System and Task Environment Effects on Ethical Judgment: An Exploratory Study of Industrial Salespeople. Organization Science, 4(4), 617-644.

Schweitzer, M.E., Ordonez, L. and Douma, B. (2004). Goal Setting as a Motivator of Unethical Behavior. The Academy of Management Journal, 47(3) June, 422-432.

Warren, D.E.(2003). Constructive and Destructive Deviance in Organizations. The Academy of Management Review, 28(4), 622-632.

Wright, P.M., Dundford, B.B. and Snell, S.A. (2001). Human resources and the resource based view of the firm. Journal of Management, 27, 701-721.

Yilmaz, C. and Hunt, Sh.D. (2001). Salesperson Cooperation: The Influence of Relational, Task, Organizational, and Personal Factors. Journal of the Academy of Marketing Science, 29(4), 335-357.

Zoltners, A.A., Sinha, P.K. and Lorimer, S.E. (2016). Are You Paying Enough Attention To Your Sales Force in Insight for Sales Force Success. ZZ Associates, Inc. 